\title{
Morphological Assessment of Newly Developed Gladiolus Hybrids (Gladiolus hybridus Hort.) for Flowering and Corm Traits under Sub- Tropical Environment of Delhi
}

\author{
Kishan Swaroop* and Kanwar Pal Singh
}

Department of Floriculture and Landscaping, ICAR-Indian Agricultural Research Institute, New Delhi-110012, India

*Corresponding author

\section{A B S T R A C T}

\section{Keywords}

Gladiolus, Hybrids, Flower traits, Vase life, Corms

\section{Article Info}

\section{Accepted:}

16 April 2021

Available Online:

10 May 2021
An experiment entitled morphological assessment of newly developed gladiolus hybrids (Gladiolus hybridus Hort.) was conducted for flowering and corm traits under sub-tropical environment of Delhi with twenty six gladiolus hybrids along with a standard check variety at the Division of Floriculture and Landscaping, ICAR-IARI, New Delhi in randomized block design with three replications during winter season 2020-21. The results of the experiment showed that hybrids such as Smokey Lady x Mayur, High Hopes Open, P-16-1 x Eurovision, Chandni x Snow Princess and Melody Open Seedling have shown earliness in flowering and took 79.66 - 85.00 days range after planting, whereas hybrids such as Pearl Beauty x Lucky Shemrock took 110.00 day followed by Vidushi (Mutant) 109.33 day, Bindiya x Creamy Green 108.66 day, Pink Parasol Open 108.33 day, Swarnima x Viola and Canada x Green Willow each 108.00 day as compared to remaining hybrids and check variety. The maximum plant height $142.00 \mathrm{~cm}$, rachis length $84.00 \mathrm{~cm}$ and number of florets per spike 20.66 was recorded in Bindiya x Creamy Green hybrid. The remaining hybrids such as Green Pasture x Regency, Smokey Lady x Oscar, Vidushi(Mutant) and S. Lady $x$ Headywine and Melody Open Seedling have also showed excellent performance in terms of plant height, spike length, rachis length and number of florets per spike respectively. Moreover, hybrids such as Bindiya Creamy Green, Green Pasture x Regency, S. Lady x Oscar, AVE x Mayur, Salmon Queen Open Seedling, High Hopes Open and Vidush (Mutant) have shown more florets (7.00 -7.66) remain open at a time as compared to check variety and other hybrids, most of them also produced three or more than three corms per plant.

\section{Introduction}

Gladiolus (Gladiolus hybridus Hort.) commonly known as "sword lily" due to its corn flag or sword shaped leaves and it grows in Africa as a weed in corn fields (Sharma $e t$ al., 2008; Singh et al., 2014). It is originated in South Africa, belongs to family Iridaceae 
and sub-family Ixiodeae and having the basic chromosome number $(X=15)$. Gladiolus is popularly known as "Queen of the bulbous flowers" it is a very prominent bulbous cut flower crop and having a more demand in domestic and international markets due to its use in bouquets, decoration of interior and also in flower arrangements (Ali et al., 2013; Kumari et al., 2014).). It is also one of the most popular landscape and cut flower industry plant (Mehra et al., 2016). Its spikes are used in flower arrangements (Rihne et al., 2017).

It is well known ornamental bulbous plant because, it has magnificient inflorescence with dazzling colours of florets long keeping keeping quality, varying forms and sizes and it can be kept in vases for about 8 to 10 days depends on varying variety and ambient conditions prevailing in the room. It is an important part in most of flower arrangements including offering in bouquets. Evaluation is a basic tool for assessing the morphological variability present in any crop species, which could be exploited for its commercialization (Amit Nishant Kujur and Sharma, 2016).

Proper screening and evaluation of hybrids/lines would provide an estimate of their potential value as suitable genotypes for commercial production and also for utilization in varietal development (Singh et al., 2017).

Hence, the present experiment was planned and conducted with objective to know the morphological assessment of new gladiolus hybrids under the Agro-climatic environment of Delhi for further commercial cultivation for different purposes.

\section{Materials and Methods}

The morphological assessment of different hybrids of gladiolus (Gladiolus hybridus Hort.) under Delhi agro-climatic environment was conducted in the Division of Floriculture and Landscaping, ICAR- Indian Agricultural Research Institute, New Delhi during winter season 2020-21 on sandy loam soil type.

The experiment was carried out using a complete randomized block design with twenty six hybrids with one standard check in three replications having $2.0 \times 2.0 \mathrm{~m}^{2}$ plot size. Hybrids were as follows: Chandni $\mathrm{x}$ Snow Princess, Bindiya $\mathrm{x}$ Creamy Green, Swarnima x Viola, P-16-1 x Eurovision, Smokey Lady x Headywine, Green Pasture $\mathrm{x}$ Regency, Smokey Lady x Oscar, Canada $\mathrm{x}$ Green Willow, Cignet x Miss America, (Green Willow $\mathrm{x}$ Cignet) $\mathrm{x}$ Little Fawn, AVE $\mathrm{x}$ Mayur, Mayur x Howard, Pearl Beauty $\mathrm{x}$ Lucky Shamrock, George Mazure x Melody, Melody Open Seedling, Salmon Queen Open Seedling, Green Lilac Open Seedling, High Hopes Open Seedling, Berlew Open Seedling, Pink Parassol Open Seedling, Smokey Lady x Mayur, Melody x Suchitra, White Song x P. Frost, White Oak x Flirt, Cignet x RTS, Vidushi (Mutant), and a check as White Prosperity. The land preparation was done including ploughing and levelling of the field and all the cultural operations were carried out uniformly during the experimental period for raising the successful crop. Healthy corms were selected for planting and spaced at $50 \mathrm{~cm}$ in double row system keeping plant to plant distance at $10 \mathrm{~cm}$. Planting depth was kept as $5-8 \mathrm{~cm}$ in soil.

Data were recorded on various growth and flowering characters viz., plant height, spike length, rachis length, number of days taken to first floret opening, number of florets per spike, floret remains open at a time and number of corms per plant. The data collected were analyzed statistically using ANOVA and compared the means of the growth, flowering and corms parameters for the gladiolus hybrids thus, analysis was done as suggested by Panse and Sukhatme (1965). 


\section{Results and Discussion}

The analysis of data indicated significant differences for all the characters showing variation in the hybrid materials.

\section{Growth characteristics}

All the hybrids of gladiolus were having the significant difference in their growth characters.

The results of the experiment showed in table 1 that hybrids such as Smokey Lady x Mayur, High Hopes Open, P-16-1 x Eurovision, Chandini x Snow Princess and Melody Open Seedling have shown as earliness in flowering and took 79.66 - 85.00 days range after planting, whereas hybrids such as Pearl Beauty x Lucky Shemrock took 110.00 day followed by Vidushi (Mutant) 109.33 day, Bindiya x Creamy Green 108.66 day, Pink Parasol Open 108.33 day, Swarnima x Viola and Canada x Green Willow each 108.00 day as compared to remaining hybrids and check variety. It is the genetic factor that expresses the difference and results clearly indicated that the genotypic difference existed with regard to growth characters. The similar results were reported by Kishan and Singh (2005). There is a particular set of period for each hybrid for flowering and results are in conformity with findings of Shaukat et al., and Poonam, K. 2012. Results were also in line with the work of Arora and Khanna (1985) and Rani et al., (2007) who reported superiority of some genotypes over other genotypes due to variation of genotypes of hybrids. Similar results have also been reported by Nagaraju and Parthasarthy (2001), Kumar and Yadav (2005), Arora and Sandhu (1987), Kem et al., (2003).The maximum plant height $142.00 \mathrm{~cm}$ and rachis length $84.00 \mathrm{~cm}$ was recorded in Bindiya x Creamy Green hybrid, whereas, spike length $128.33 \mathrm{~cm}, 121.00 \mathrm{~cm}, 116.33$ $\mathrm{cm}$, and 116.00 was recorded in hybrids such as Salmon Queen Open Seedling, Green Pasture x Regency, Bindiya x Creamy Green, Vidushi (Mutant) and S. Lady x Headywine respectively. The maximum and minimum plant height in hybrids may be due to the hereditary traits or prevailing environmental conditions of the growing location Kumari and Kumar (2015). The hybrids studied had shown highly significant difference with respect to spike and rachis length that are important characters for quality assessment. The results are also in accordance with the findings of Nair and Shiva (2003) in gladiolus and similar variations for plant height was also observed by Kalasaraddi (1996) and Shiramgond (1997), Sidhu and Arora (2000) in different gladiolus genotypes. Variation in gladiolus genotypes generally revealed exotic nature and exhibit genetic basis for the expression of certain useful traits. Misra and Singh (1998) and Anuradha and Gowda (1990) also observed the same results. Rachis length is important trait for gladiolus cut flower and variation in results are in accordance with the findings of Gupta et al.,(2001, Hegde 1996).

Flower, corm traits, vase life and spike longevity

In International market, the number of florets per spike should be more than 16. But, the newly developed hybrids recorded maximum number of florets per spike as 20.66,19.66 and 19.00 in hybrids namely Bindiya x Creamy Green, S. Lady x Oscar, S. Lady x Headywine and Melody Open Seedling respectively (table 2 ). The variation in number of florets per spike might be due to hereditary traits of the hybrids. Similar results on number of florets per spike were reported by Rani and Singh (2005) and Ram et al., (2005). Number of floret remains open at a time were seen maximum in hybrids such as Salmon Queen Open Seedling and Smokey Lady x Oscar each (7.66), whereas, it was 7.33 in AVE $x$ Mayur hybrid. 
Table.1 Performance evaluation of gladiolus hybrids for days to first flowering, plant height, spike length and rachis length

\begin{tabular}{|c|c|c|c|c|c|}
\hline S. $\mathbf{N}$. & Hybrids & $\begin{array}{l}\text { Days to first } \\
\text { flowering }\end{array}$ & $\begin{array}{l}\text { Plant height } \\
\text { (cm) }\end{array}$ & $\begin{array}{c}\text { Spike } \\
\text { length }(\mathrm{cm})\end{array}$ & $\begin{array}{l}\text { Rachis length } \\
\text { (cm) }\end{array}$ \\
\hline 1. & Chandni x Snow Princess & 85.00 & 104.00 & 86.33 & 55.66 \\
\hline 2. & Bindiya x Creamy Green & 108.66 & 142.00 & 116.33 & 84.00 \\
\hline 3. & Swarnima x Viola & 108.00 & 123.33 & 106.00 & 54.00 \\
\hline 4. & P-16-1 x Eurovision & 84.66 & 120.00 & 104.33 & 71.00 \\
\hline 5. & Smokey Lady x Heady Wine & 107.66 & 130.33 & 116.00 & 61.00 \\
\hline 6. & Green Pasture x Regency & 107.00 & 132.66 & 121.00 & 62.00 \\
\hline 7. & Smokey Lady x Oscar & 105.00 & 121.66 & 108.00 & 56.66 \\
\hline 8. & Canada $x$ Green Willow & 108.00 & 131.00 & 115.00 & 53.00 \\
\hline 9. & Cignet x Miss America & 107.66 & 113.00 & 99.33 & 43.66 \\
\hline 10. & (Green Willow x Cignet) x Little Fawn & 106.33 & 105.00 & 88.66 & 62.00 \\
\hline 11. & AVE x Mayur & 93.33 & 106.00 & 98.00 & 51.33 \\
\hline 12. & Mayur x Howards & 106.00 & 107.66 & 96.00 & 57.66 \\
\hline 13. & Pearl Beauty x Lucky Shemrock & 110.00 & 104.66 & 91.33 & 54.00 \\
\hline 14. & George Mazure x Melody & 100.33 & 95.00 & 83.00 & 47.33 \\
\hline 15. & Melody Open Seedling & 84.66 & 123.00 & 115.00 & 65.66 \\
\hline 16. & Salmon Queen Open Seedling & 97.33 & 132.00 & 128.33 & 61.33 \\
\hline 17. & Green Lilac Open Seedling & 107.00 & 121.00 & 112.00 & 75.00 \\
\hline 18. & High Hopes Open Seedling & 84.66 & 113.00 & 95.33 & 54.00 \\
\hline 19. & Berlew Open Seedling & 102.00 & 111.66 & 99.66 & 62.66 \\
\hline 20. & Pink Parassol Open Seedling & 108.33 & 120.33 & 111.33 & 61.00 \\
\hline 21. & Smokey Lady x Mayur & 79.66 & 114.33 & 102.00 & 53.00 \\
\hline 22. & Melody x Suchitra & 96.66 & 104.33 & 82.66 & 46.66 \\
\hline 23. & White Song x P.Frost & 104.33 & 105.00 & 96.33 & 58.00 \\
\hline 24. & White Oak x Flirt & 99.33 & 101.33 & 86.33 & 41.00 \\
\hline 25. & Cignet x RTS & 98.66 & 116.66 & 105.00 & 63.33 \\
\hline 26. & Vidushi (Mutant) & 109.33 & 127.00 & 116.00 & 65.66 \\
\hline \multirow[t]{3}{*}{27.} & White Prosperity (check) & 104.00 & 108.66 & 94.00 & 54.66 \\
\hline & $\mathrm{C} \mathrm{D}$ at $5 \%$ & 4.569 & 5.094 & 3.095 & 3.820 \\
\hline & C V. & 2.767 & 2.670 & 1.833 & 3.984 \\
\hline
\end{tabular}


Table.2 Performance evaluation of gladiolus hybrids for flowering, corm traits, vase life and spike longevity

\begin{tabular}{|c|c|c|c|c|c|c|}
\hline $\begin{array}{c}\text { S. } \\
\text { No. }\end{array}$ & Hybrids & $\begin{array}{l}\text { Number } \\
\text { of florets } \\
\text { per spike }\end{array}$ & $\begin{array}{c}\text { Floret } \\
\text { remains } \\
\text { open at a } \\
\text { time }\end{array}$ & $\begin{array}{l}\text { Vase life of } \\
\text { spike in } \\
\text { tap water } \\
\text { (day) }\end{array}$ & $\begin{array}{l}\text { Field life of rachis } \\
\text { longevity/Duration } \\
\text { of flowering }\end{array}$ & $\begin{array}{l}\text { Number } \\
\text { of corms } \\
\text { per plant }\end{array}$ \\
\hline 1. & Chandni x Snow Princess & 17.66 & 6.66 & 16.00 & 29.66 & 2.66 \\
\hline 2. & Bindiya x Creamy Green & 20.66 & 7.00 & 14.66 & 27.33 & 3.33 \\
\hline 3. & Swarnima $x$ Viola & 17.00 & 6.66 & 13.33 & 30.00 & 2.66 \\
\hline 4. & P-16-1 x Eurovision & 17.66 & 5.66 & 15.00 & 30.00 & 2.33 \\
\hline 5. & Smokey Lady x Heady Wine & 19.00 & 6.66 & 14.33 & 29.33 & 2.66 \\
\hline 6. & Green Pasture x Regency & 18.66 & 7.00 & 14.00 & 25.66 & 3.00 \\
\hline 7. & Smokey Lady x Oscar & 19.66 & 7.66 & 16.66 & 30.66 & 3.33 \\
\hline 8. & Canada x Green Willow & 16.66 & 6.66 & 16.00 & 28.00 & 2.33 \\
\hline 9. & Cignet $\mathrm{x}$ Miss America & 16.33 & 6.33 & 15.00 & 28.33 & 2.00 \\
\hline 10. & $\begin{array}{l}\text { (Green Willow x Cignet) } \mathrm{x} \\
\text { Little Fawn }\end{array}$ & 16.66 & 6.00 & 13.00 & 31.00 & 2.33 \\
\hline 11. & AVE x Mayur & 18.66 & 7.33 & 16.66 & 26.33 & 2.66 \\
\hline 12. & Mayur x Howards & 18.00 & 6.33 & 15.33 & 31.00 & 2.33 \\
\hline 13. & Pearl Beauty x Lucky Shemrock & 17.66 & 6.66 & 16.00 & 29.33 & 2.33 \\
\hline 14. & George Mazure x Melody & 14.33 & 6.00 & 15.33 & 28.00 & 2.00 \\
\hline 15. & Melody Open Seedling & 19.00 & 6.00 & 14.33 & 25.00 & 2.66 \\
\hline 16. & Salmon Queen Open Seedling & 18.66 & 7.66 & 15.00 & 20.00 & 2.66 \\
\hline 17. & Green Lilac Open Seedling & 18.00 & 6.00 & 15.00 & 30.33 & 2.33 \\
\hline 18. & High Hopes Open Seedling & 17.66 & 7.00 & 15.33 & 32.33 & 2.33 \\
\hline 19. & Berlew Open Seedling & 18.33 & 5.66 & 14.33 & 31.00 & 2.33 \\
\hline 20. & Pink Parassol Open Seedling & 17.66 & 5.66 & 13.00 & 29.33 & 3.00 \\
\hline 21. & Smokey Lady x Mayur & 16.66 & 6.33 & 13.66 & 27.66 & 2.33 \\
\hline 22. & Melody x Suchitra & 17.66 & 6.00 & 16.33 & 21.00 & 2.33 \\
\hline 23. & White Song x P.Frost & 17.66 & 4.66 & 17.00 & 26.00 & 2.00 \\
\hline 24. & White Oak x Flirt & 17.33 & 6.00 & 16.00 & 31.33 & 2.33 \\
\hline 25. & Cignet x RTS & 17.00 & 6.00 & 12.66 & 31.33 & 2.33 \\
\hline 26. & Vidushi (Mutant) & 19.33 & 7.00 & 14.00 & 33.00 & 2.33 \\
\hline \multirow[t]{3}{*}{27.} & White Prosperity (check) & 16.00 & 5.33 & 12.33 & 27.33 & 1.66 \\
\hline & $\mathrm{C} \mathrm{D}$ at $5 \%$ & 1.303 & 1.251 & 2.132 & 2.038 & 0.132 \\
\hline & C V. & 4.465 & 11.953 & 8.750 & 4.347 & 12.500 \\
\hline
\end{tabular}

The maximum vase life of spike in normal tap water $17.00,16.66$ and 16.00 days was observed in White Song x P. Frost, AVE x Mayur, Chandni x Creamy Green, Canada $\mathrm{x}$ Green Willow and Pearl Beauty $\mathrm{x}$ Lucky
Shemrock hybrids respectively. But, it was minimum (12.33 day) in check variety, since the vase life is important crucial character for cut flower in gladiolus and variation in results are in accordance with the findings of Gupta $e t$ 
al.,(2001).The range of field life of rachis or duration of flowering was observed from 20.00 to 33.00 days and it was maximum 33.00 and 32.33 days in Vidushi (Mutant) and High Hopes Open seedling hybrids respectively.

The maximum number of corms per plant 3.33 was recorded in Bindiya $x$ Creamy Green and S. Lady $\mathrm{x}$ Oscar each and it was minimum 1.66 corms per plant in White Prosperity (Check).Moreover, many hybrids such as Chandni x Snow Princes, Swarnima x Viola, Smokey Lady x Headywine, AVE x Mayur, Melody Open Seedling and Salmon Queen Open Seedling had also produced 2.66 corms per plant each.

The variation in number of corm per plant in various hybrids of gladiolus might be due to the genetic makeup of hybrids. Similar results were also reported by Zubair et al., (2013).Moreover hybrids varied in the corm production depending upon their hereditary traits. Rao and Sushma (2015), Jana and Das (2013), Shaukat et al., (2012), Hossain et al., (2011) also observed variations in the number of corms of different gladiolus. These findings confirm the results of present investigation. Similar results have also been reported by Momin et al.,(2015), Churasia et al.,(2015), Naresh et al., (2015), Saleem et al., (2013), Sarkar and Chakraborty (2014).

The results obtained from the present study indicated that, out of the twenty six gladiolus hybrids studied, Bindiya x Creamy Green was found to be the most promising in respect to plant height, rachis length, number of florets per spike and corm yield characters.

Hybrids such as Smokey Lady x Mayur, High Hopes Open, P-16-1 x Eurovision, Chandni x Snow Princess and Melody Open Seedling showed earliness in flowering under subtropical environment of Delhi.

\section{References}

Amit Nishant Kujur, T. and Sharma, G. (2016). Varietal evaluation of gladiolus (Gladiolus hybridus Hort.) under Chhatisgarh plains. Journal of Ornamental Horticulture, 19 (1 \& 2): 48-52.

Ali, M., Hussain, R., Bashir, A., Raza, S. and Ahmad, N.D.A. (2013). Investigation of bio fertilizers influence on vegetative growth, flower quality, corm yield and nutrient uptake in gladiolus (Gladiolus grandiflorus L.) International Journal of Plant Animal Envirnomental Science, 4(1): 94-99.

Arora, J. S. and Khanna, K. (1985). Evaluation of gladiolus cultivars. Journal of Research of Punjab Agricultural Unversity, 22 (4):655662.

Arora, J. S. and Sandhu, G. S. (1987). Effect of two planting dates on the performance of fifteen gladiolus cultivars. The Punjab Horticulture Journal, 27 (4):243-249.

Anuradha, S. and Gowda, J. V. N. (1990). Genetic variability in gladiolus. Progressive Horticulture, 22 (1-4):5559.

Chourasia, A., Viradia, R. R., Ansar, H. and Shubham, N. M. (2015). Evaluation of different cultivars of gladiolus for growth, flowering, spike yield and corm yield under Saurashtra region of Gujarat. The Bioscan, 10 (1):131-134.

Gupta, S. R., Singh, A. K. and Singh, O. P. (2001). Variation for flowering characters and their vase life in gladiolus (Gladiolus floribundus L.). Advance PlantScience, 14:133-136.

Hegde, M. V. (1996). Studies on variability, correlation, path analysis and performance of Gladiolus hybridus. $M$. Sc. (Agri.) Thesis, University Agricultural Sciences, Dharwad. 
Hossain, M. D., Talukder, K.H., Asaduzzaman, M., Mohmud, F., Amin, N. and Sayed, M. A. (2011). Study on morphological characteristics of different genotypes of gladiolus flower. Journal of Science Foundation, 9 (1\&2):01-08.

Jana, B. R. and Das, B. (2013). Evaluation of tropical gladiolus under eastern plateau and hill region of India. International Journal of Science and Research,47(7):1301-1302.

Kalasaraddi, P. (1996). Effect of time of planting and cover rise on growth, flowering and flower quality of gladiolus (Gladiolus hybridus Hort.) M.Sc. (Agri.)Thesis, University Agricultural Sciences, Dharwad.

Kem, J. C., Yadav, S. K. and Kumar, S. (2003). Performance of gladiolus cultivars under Valley of Uttaranchal. Progressive Horticulture,35 (1): 108110.

Kishan, P. K. and Singh, K. P. (2005). Performance of gladiolus under Delhi conditions. Journal of Ornamental Horticulture, 8:32-35.

Kumar, R. and Yadav, D. S. (2005). Evaluation of gladiolus cultivars under sub-tropical hills of Meghalaya. Journal of Ornamental Horticulture, 8(2): 86-90.

Kumari, R. V., Kumar, D. P., Arunkumar, B., \& Mahadevamma, M. (2014). Effect of integrated nutrient management on floral and cormal parameters in gladiolus (Gladiolus hybridus L.). International Journal of Agricultural Sciences, 10(1), 15-22.

Kumari, K. and Kumar, S. (2015). Evaluation of performance of gladiolus varieties for vegetative, floral and corm \& cormel characters under Tarai conditions. International Journal of Tropical Agriculture,33 (2):16171620.
Kumari, Poonam. (2012). Morphological and molecular characterization of Fusarium wilt resistance in gladiolus (Gladiolus $x$ Hybridus Hort.) M.Sc. (Hort.) Thesis submitted to the University of Horticultural Sciences, Bgalkot, Bangaluru, India.

Mehra, T. S., Kalkame, C. H., Momin., Tomar, K. S., Kumar, Nilay and Pandy, A. K. (2016). Performance of gladiolus (Gladiolus grandiflorus L.) cultivars under Pasighat conditions of Arunachal Pradesh. Journal of Ornamental Horticulture, 19 (1 \& 2): 19-22.

Momin, B., Kumar, S., Momin, K. and Dewan, N. (2015). Evaluation of gladiolus (Gladiolus grandiflorus L.) genotypes under West Garo hills district, Meghalaya. Hortflora Research Spectrum,4 (3): 224-229.

Misra, R. L. and Singh, B. (1998). Gladiolus in Commercial Floriculture (Bose, T.K. and L.P. Yadav): pp 267-353, Maya Prakash, Calcutta.

Nagraju, V. and Parthasarthy, V. A. (2001). Evaluation of gladiolus germplasm at mid hills of Meghalaya. Indian Journal of Horticulture, 58 (3):269-275.

Naresh, S., Rao, A. V. D., Bhaskar, V., Uma, K. and Rao M. P. (2015). Evaluation of gladiolus (Gladiolus hybrida L.) hybrids under coastal Andhra Pradesh conditions. Plant Archives, 15 (1):451454.

Nair, S. A. and Shiva, K. N. (2003). Performance of selected gladiolus (Gladiolus floribundus L.) varieties under Bay Islands conditions. Indian Journal of AgricultureSciences,75: 397-398.

Panse, V. G. and Sukhatme, P. V. (1965). Statistical Methods for Agricultural Workers, Indian Council of Agricultural Research, New Delhi, pp: 145-149. 
Ram, R. B., Tomar, K. S. and Datta, S. K. (2005). Performance of certain gladiolus varieties under sodic conditions. Journal of Ornamental Horticulture, 8 (1):77-78.

Rao, K. D. and Sushma, K. (2015). Performance of different new genotypes of gladiolus. Agric. Sci. Digest, 35 (2):134-137.

Rani, R. and Singh, C. (2005). Evaluation of different gladiolus cultivars for quality flower production. Journal ResearchBirsa Agricultural University, 17(2):227-230.

Rani, R., Prasad, K. K., and Ranjan. R. (2007). Study on varietal performance in gladiolus. The Orissa Journal of Horticulture, 35(2):35-38.

Rihne, T., Singh, Chaoba V., Singh, A. Herojit., Singh, R.K. Dilip and Singh, N. Okendro (2017). Effect of foliar application of micro nutrients on growth, flowering and yield of gladiolus (Gladiolus grandiflorus L.), Journal of Ornamental Horticulture, 20 (3 \& 4):113-119.

Saleem, M., Ahmad, I. and Khan, M. A. (2013). Cultivar effects on growth, yield and cormel production of gladiolus (Gladiolus floribundus L.). Journal of Ornamental and Horticultural Plants, 3(1):39-48.

Sarkar, I. and Chakraborty, S. (2014). Varietal performance on important floral attributes of 15 indigenous and exotic varieties of gladiolus in North eastern Himalaya region. Journal of Agriculture Technology, 1 (1):80-85.

Shaukat, S. A., Shah, S. Z. A., Shaukat, S. K. and Shoukat, S. W. (2012). Evaluation of different gladiolus cultivars under Union Council Bangoin Pooch Jammu and Kashmir Conditions. Journal of Agricultural Science and Applications., 1(4):139-142.

Sharma, U., Chaudhary, S. V. S. and Thakur, R. (2008). Response of gladiolus to integrated nutrient management. Haryana Journal Horticulture Science, 37(3\&4): 285-286.

Shiramgond. (1997). Evaluation of varieties in gladiolus under Ghataprabha Command Area. M.Sc. (Agri.)Thesis, University Agricultural Sciences, Dharwad.

Sidhu, G. S. and Arora, J. S. (2000). Evaluation of gladiolus varieties for summer flower production. Proc. Of the National Conference on Gladiolus, January, pp; 115-117.

Singh, R., Kumar, M., Raj, S. and Kumar, S. (2014). Effect of integrated nutrient management (INM) on growth and flowering in gladiolus (Gladiolus grandiflorus L.) cv. White Prosperity. Annals of Horticulture, 6(2): 251-258.

Singh, Anil K., Sisodia, A., Sisodia, V. and Priyabrata, Ray. (2017). Performance of Indian and Exotic varieties of gladiolus under Eastern U.P. conditions. Journal of Ornamental Horticulture, 20 (3 \& 4): 153-157.

Zubair, M., Ayub, G., Rab, A., Amin, N., Ahmad, M. and Ara, N. (2013). Preflowering growth of gladiolus in response to staggered planting. Pakistan Journal of Botany, 45(4):1329-1338.

\section{How to cite this article:}

Kishan Swaroop and Kanwar Pal Singh. 2021. Morphological Assessment of Newly Developed Gladiolus Hybrids (Gladiolus hybridus Hort.) for Flowering and Corm Traits under SubTropical Environment of Delhi. Int.J.Curr.Microbiol.App.Sci. 10(05): 538-545. doi: https://doi.org/10.20546/ijcmas.2021.1005.061 